\title{
SEPT4 Gene
}

National Cancer Institute

\section{Source}

National Cancer Institute. SEPT4 Gene. NCI Thesaurus. Code C104502.

This gene is involved in both cytoskeletal maintenance and GT Pase activity. 